\title{
PROBLEMATIC APPLICATION OF CRIMINAL REVOCATION OF POLITICAL RIGHTS IN PERSPECTIVE OF CORRUPTION LAW
}

\author{
Edi As'Adi \\ Doctoral Program of Legal Studies, University of Diponegoro \\ E-mail: 454dilaw@gmail.com
}

\begin{abstract}
The spirit of fighting corruption in Indonesia based on the spirit of the Declaration of the 8th International Conference against Corruption and Indonesia United Nations Convention against Corruption (UNCAC) UN 58/ 4 dated October 31, 2003, and Law No. 7 of 2006 on the Ratification of the UN Convention on Anti-Corruption of 2003 and Act No. 20 of 2001. The implementation of the Law on Corruption tends not optimal. As a new breakthrough reached the imposition of criminal sanctions in the form of revocation of political rights for the accused of corruption. Although in practice the criminal is considered unconstitutional. Given the enormous impact of corruption, namely the loss suffered by the people and the state, the current criminal disenfranchisement for perpetrators of political corruption has been duly applied.
\end{abstract}

Key words: criminal law, corruption, criminal corruption, political rights.

\section{Abstrak}

Semangat pemberantasan korupsi di Indonesia dilandasi semangat Declaration of $8^{\text {th }}$ International Confrerence Against Corruption dan Indonesia United Nations Convention Against Corruption (UNCAC) PBB No. 58/4 tanggal 31 Oktober 2003, dan UU Nomor 7 Tahun 2006 tentang Pengesahan Konvensi Perserikatan Bangsa-Bangsa Anti Korupsi 2003 dan UU Nomor 20 Tahun 2001. Implementasi UU Tindak Pidana Korupsi cenderung belum optimal. Sebagai trobosan baru ditempuh penjatuhan sanksi pidana berupa pencabutan hak politik bagi terdakwa korupsi.

Kata kunci: hukum pidana, korupsi, pelaku korupsi, hak politik.

Preface

State commited to the eradication TIPIKOR with massive and comprehensively, because in 2013 the crime of corruption is rampant and keep moving to hamper the progress of economic development, social, political, and cultural, altough some people consider that the government's efforts as a form of primilary imaging, and as law enforcement was considered tend to be selective. Corruption eradication effort has increased siginificantly which is numbered 821 or 32,10 percent of the total specific criminal case recevied by the MA RI totaled 2558 cases, this thing can be seen through the annual reports of the Supreme Court in 2013 as following:

Tabel 1. Classification of special criminal appeal cases received by the Supreme Court in 2013

\begin{tabular}{|c|l|c|c|}
\hline NO. & CLASSIFICATION & NUMBER & $\%$ \\
\hline 1 & Corruption & 821 & $32,10 \%$ \\
\hline 2 & $\begin{array}{l}\text { Narcotics and } \\
\text { Psychotropic }\end{array}$ & 713 & $27,87 \%$ \\
\hline 3 & Child Protection & 498 & $19,47 \%$ \\
\hline 4 & $\begin{array}{l}\text { Harshness of the } \\
\text { house hold }\end{array}$ & 127 & $4,96 \%$ \\
\hline 5 & Forestry & 70 & $2,74 \%$ \\
\hline 6 & Oil and Gas & 54 & $2,11 \%$ \\
\hline 7 & Customs & 38 & $1,49 \%$ \\
\hline 8 & IPR & 33 & $1,29 \%$ \\
\hline 9 & Fisheries & 26 & $1,02 \%$ \\
\hline 10 & Banking & 22 & $0,94 \%$ \\
\hline 11 & Housing & 15 & $0,86 \%$ \\
\hline 12 & Enviromentalists & 15 & $0,59 \%$ \\
\hline 13 & Human Trafficking & 12 & $0,47 \%$ \\
\hline 14 & Health & 12 & $0,47 \%$ \\
\hline 15 & Firearm & 10 & $0,39 \%$ \\
\hline 16 & $\begin{array}{l}\text { Consumer } \\
\text { Protection }\end{array}$ & 9 & $0,35 \%$ \\
\hline 17 & Money Loundering & 7 & $0,27 \%$ \\
\hline 18 & Employment & 6 & $0,23 \%$ \\
\hline 19 & Pornography & & \\
\hline
\end{tabular}




\begin{tabular}{|l|l|c|c|}
\hline 20 & Taxation & 5 & $0,20 \%$ \\
\hline 21 & Terrorism & 1 & $0,04 \%$ \\
\hline 22 & Other & 40 & $1,56 \%$ \\
\hline \multicolumn{2}{|c|}{ Total } & $\mathbf{2 5 5 8}$ & $\mathbf{1 0 0 \%}$ \\
\hline
\end{tabular}

Based on the above facts, it can be said that the actual assessment of the problems in the implementation of political crime in the perspective of corruption (here in after abbrevied TIPIKOR) are very important, since in some cases of the corruption that have been or are being examined in court corruption oftenly rejected by the panel of judges.

Based on the description, the problem arises that if it is feared could be lead to the pros and cons in the community, which is how the existence of the normative regulation corruption today? Why the implementation of the demands of political disfranchisement can't be applied in the handling of corruption? How should be the political corruption law in the future?

\section{Discussion}

\section{Current Normative Existence of Corruption Setting.}

Political Rights in Theory of Law and State (General Theory and State) from Hans Kalsen means that citizen can participate in the making of laws or regulations or politics, through its participation to vote in the direct or indirect democracy. Politics is a form of human activity in which related to the structing the soceity from the perspective of freedom. ${ }^{1}$

Eradication corruption's essentially is a question of law culture organizers latent state administration or crucial to be resolved. Legal issues crucial is how legal principles are philosopical, juridical and sociological as an objective legal priciple is translated into legal norm in the form of legislation or at least government regulations which is governing the aspect of administration as an objective priciple that must be follow in eradication of corruption.

The existence of the normative corruption regulation actually has been formulated sin-

Bernard Arief Sidharta, 2009, Meuwissen Tentang Pengembanan Hukum, Ilmu Hukum, Teori Hukum dan Filsafat Hukum, Bandung: Refika Aditama, page.105. ce the Dutch colonia era anfd became the priorty in the law enforcement its proved in Wetboek van Strafrecht (hereinafter abbreviated WvS) in Article VI of the Act No. 1 with its original name Wetboek van Strafrecht voor $\mathrm{Ne}$ derlandsch-Indie prevailed on March 8, 1942, which was later adopted by the State of Indonesia as Criminal Code with changes and addition to the Law of its mother (WvS).

Formulation of corruption in the WvS indicate that this corruption issue has become chronic and increasingly complex. It then becomes a big question for the wider community who care about "honestly" and "prosperity" for all Indonesian people, wheter the corruption in Indonesia is able to eridicate until the roots? Despite all means have been taken either by the rules of criminal law and the mechanism of handling the corruption which is this extra ordinary crime.

The mother of eradication TIPIKOR essentially is Second Book Title Chapter XXVIII On Crime Position which is related to Act of Criminal Corruption among others, Article 415, Article 416, Article 417, Article 418, Article 419, Article 420, Article 423, Article 424, Article 425, Article 426 , Article 427 and Article 435 of the Criminal Code which is then to now this has been included into its Special Law those are Act No. 31 of 1999 on Corruption Eradication, as amended by Act No. 20 of 2001, as stated in Article 5 until Article 12. The existence of the normative corruption regulation is based on the spirit of international corruption eradication which is based on the results of the decision of the Declaration of $8^{\text {th }}$ International Conference Against Corruption in Lima on 7-11 September 1977 , then the results of the declaration is ratified by the government of Indonesia United Nations Convention Against Corruption (UNCAC) is based on the United Nations resolution 58/4 on October 31, 2003 as specified in Act No. 7 of 2006 on the Ratification of the UN Convention Against Corruption 2003. ${ }^{2}$ Formulation of the

Artidjo Alkostar, "Permasalahan Gratifikasi dan Pertanggungjawaban Korporasi dalam Undang-Undang Korupsi”, Varia Peradilan, Vol. XXVIII, No. 330, May 2013, Jakarta: Ikatan Hakim Indonesia, page. 41. 
Criminal Code and the provisions of the UNCAC convention furthermore transformed into a specially Act of Criminal Corruption, that is Law No. 30 of 2001 on the Corruption Eradication Commision and Law No. 20 of 2001, as stated in Article 5 until Article 12.

\section{Revocation Political Rights in Handling Act of Criminal Corruption Versus Constitutional Rights.}

Nowadays the condition is starting to change, Article 28 in conjunction with Article 28E Paragraph (3) 1945 Constitution stated that essentially the right to choose and select or political rights is a fundamental right of every people of Indonesia and guaranteed by the state trough Article 28E Paragraph (3) which formulate that: "Everyone has a right to freedom of association, asembly, and expression".

The existence of corruption have a close link with the state organizer's cultural aberration which tends to deprive the human rights or many people, in perhaps the state organizer's whose aberrate should disfranchisement of their political rights in order to protect the progress, maintaining the law and to fulfill the human rights by the state through the Government, as mandated in Articel 28I Paragraph (4) 1945 Constitution. The effort of KPK to revoke the political rights is oftenly experiencing the problem in examination of the judges. This thing can be seen in some cases of corruption, following.

First, Joko Susilo corruption case on June 4,201 , the Supreme Court verdict in the decision decided: the Supreme Court uphold the adjudication of Jakarta High Court that punished djoko with 18 years in prison and a criminal fine of Rp 1 billion and Rp 32 billion replacement of punishment; and revoke Djoko Susilo right to elect and to be elected in public position (or revocation of political rights).

That adjudication is verdict handed down by the appeal tribunal headed Chairman of the Chamber of Criminal Supreme Court Artidjo Alkostar with judges of MS Lumme and M. Askin ago. The assembly agreed that Joko is convicted of corruption in the project of driving licen- se (SIM) exam simulator two-wheel and fourwheel and conduct money laundering. Previously, the Corruption Court convict 10 years in prison and criminal fine of Rp 500 billion and does not impose the additional criminal resitution. However, that decision is exacerbated by the Jakarta High Court, which are increased the sentenced to 18 years in prison and criminal fine of Rp. 1 billion, ordered to payment the replacement of Rp. 32 billion. Assembly appeal which is led by Roki Pandjaitan also revoke Djoko Susilo's political right.

Departing from Djoko Susiko cases it can be concluded that in the principle politic to revoke the political right by the assembly appeal is the form of the legal policy or hukum politik based on the idea of progresive legal, which in that case the judge belive that the consequence of the defendant depravity the state and the people's is the victims of the crime. It means the defendant as the official who is understanding the law and considered to hamper the national aim to protect the right of the people in prosperity and safety according to social justice.

Concerning that defendant of the corruption as to the whole of the Indonesian people rights in achieving the prosperity, and including human rights (HAM), is in to the qualified to the extra ordinary crimes. State obligated and responsible (orga omnes obligation) to protect the peoples right with prosecution the indemnification and giving sanction including to revoke the politicals right in addition of aberration from the defendant which rampant the peoples right, by the Corruption court.

Perhaps the reason to revoke the politicals right of the defendant is that the corruption defendant has already disturbing the process of the democracy itself or hampering the process of the politics and the wheel of administration in the state which is clean and good (good government and clean government) and be related with violation of human rights, this matter in line with the statement of Larry Diamond in his book "The Spirit of Democracy" as cite by Artidjo Akostar in his article with the title "The Problems in Bonus and The Responsi- 
bility in Corporation in Corruption Laws" in Variety of Judicature No. 330 May 2013, Larry said that:

To be Sure, Indonesia remains a troubled democracy with an extremely weak rule of law (ROL). Abuse of public office for private gain remains endemic... Corrupts relationships between powerful private actors, government bureaucrats, politicians and security officials infuse the political system and undermine if from within. As a result oligarchic business interest exercise a preponderant influence on parties, legislatures, and the execute-ve. Corruption seeps deep into many lo-cal administration, often hand in hand with egregious human right abuses. ${ }^{3}$

The decision of judges casation assembly to revoke the political rights of the defendant, is very have a base because when the act of the defendant is continued is not quickly handling its fearing tend to causing continuinfg crimes in every dimension either in politics or birocration, and the goal o the law itself to create the justice, benefitely, assurance of legal and guarantee of prosperity and happiness will came out from the 'ring'.

In the case of corruption which is engage two people that is M. Nazaruddin and Angelina Patricia Pingkan Sondakh, it seems the Judges Assembly is not verdicted the punishment to revoke the political rights of that defendants, as seen on each decision of the Indoensian Supreme Court in that case following:

Second, in the decision of the act of corruption crimes No. 2223 K/Pid.Sus/2012 with defendant M. Nazarudin, verdicted that: declare that defendant MUHAMMAD NAZARUDDIN, $\mathrm{SE}$, is proven legally and convinced according to the law is guilted to act of corruption crimes as has been sets and threatning the criminal punishmnet in Article 12 letter B Act of No.31 of 1999 as has been changed by Act of No.20 of 2001; and verdicted a criminal punishment to defendant Muhammad Nazaruddin, SE, is criminal punishment of 7 years in prison and so on;

Third, In the decision of act of corruption crime cases NO. $1616 \mathrm{~K} /$ pid.Sus/2013 with

$3 \quad$ Ibid, page 42. defendant Angelina Patricia Pingkan Sondakh, as seen on each decision of the Indonesian Supreme Court in that case following: declare that defendant ANGELINA PATRICIA PINGKAN SONDAKH, is proven legally and convinced according to law is gulited to act of corruption crimes as has been sets and threatning the criminal punishment in Article 1 letter A conjuction with Article 18 Act of No. 31 of 1999 as has been changed by Act No.20 of 2001 conjuction with Article 64 Paragraph (1) Criminal Code; verdicted a criminal punishment to defendant ANGELINA PATRICIA PINGKAN SONDAKH, is a criminal punishment of 12 years in prison and so on; and verdicted an additional criminal punishment of replacement payment with the amount of Rp12.580.000.000,00 and so on.

Depart from Indonesian Supreme Court command decision it can be conclude that even the judge have the authority to keep channeling the emptyness of law as mentioned in $\mathrm{Ar}$ ticle 24 A Paragraph (1) 1945 Indonesia Constitusional, but then in the act of criminal cases it doesn't verdicted a criminal punishment such a revoke the political rights for both of them. Perhaps in this matter the judges assembly tend to be not taking any risk if the decision is cancelled by the consequences of ultra petita, and there are still exsist a suspicion said that a political rights is still a part of human rights.

\section{The Law of Political Corruption In the Future}

The amount of state loss caused by the act of corruption crimes in Indonesia its belongs to very high and remains increasing. This fact was revealed by Attorney General in his speech which is delivered in the Symposium and National Deliberative Council MAHUPIKI in Makassar, March 18, 2013, with the title "Recapitulation of Politic Crimes and The Perspective of Criminology in Law Enforcement", it said that the losses of the state caused by the act of corruption crimes in periods 2004-2011 amounted to Rp 39,3 trilion. ${ }^{4}$

Romli Atmasasmita, "Korporasi Sebagai Subjek Tindak Pidana Korupsi”, Varia Peradilan, Vol. XXVIII, No. 330, May 2013, Jakarta: Ikatan Hakim Indonesia, Jakarta, page 38 . 
Observing that amount of losses, it proves that all this time the eradication of act of corruption as a white collar crime is tend to be hampering, as revealed by Van Den Heuvel by his short paper entitled "Corporate Crime from Criminology Perspective", Heuvel mentioned that there are 5 (five) factor that hampering the eradication of corruption, there are: inadequate and badly drafted laws; the inadequate and unreliable mechanism for detection; complexity of the creation of evidence; the Judge and his judgement at the trial; and conviction and againts whom.

Considering that five hampering factors is like tend to be disturbing the spirit of eradicating of the act of corruption crimes, threrefore, its needed agenda of politicals law or legal policy that have progresive base with basic assumption that law for the human, ${ }^{5}$ it means the politicals law in the next day is more give pressure to the sub cultural law system than the law substantion and law structure.

The law has a dynamics that can be known by thought investigation and the principles that happened in the past, it uses to set up today and predicting what will happen in the next. ${ }^{6}$ Concept of revocation the politicals right for the defendant therefore it should have been always be implented, altough it seen againts the constitution, but for the sake of justice for the people and the state whom already seized their private law by the corruptor, so then the revocation of politicals right is must be applied.

Concepts of revocation of politicals right for the corruptor from the sideview of Nonet and Selznick is as a form of politics law in the context of responsive law, not only talk about the positive law, because in the reality the positive law especially in the transition situation, is not capable enough to give the benefit to create the real justice (substansial justice) for

Satjipto Rahardjo, 2006, Membedah Hukum Progresif, Jakarta: PT. Kompas Media Nusantara, page 56-63.

Husen Alting, "Penguasaan Tanah Masyarakat Hukum Adat ((Suatu Kajian Terhadap Masyarakat Hukum Adat Ternate)", Jurnal Dinamika Hukum, Vol. 11 No. 1, Januari 2011, Purwokerto: Law Faculty of Jenderal Soedirman University, page 89. all of the people and the state whom already take the consequence of the act of the corruptor. Satjipto Rahardjo with the principle of progrsive law, is more directly to explain why the legal must capable tocreate the substantial justice. According to Satjipto Rahardjo, the way of law which remains dominated by "legally with the rules" than "legally with common sense" is the minimalist legally, that is only do the legal with implementing what is wrote on the text with raw. The supremacy of legal, as seen on the principle rule of law, just only remains explaining that the states is order according to the law which has made and deserved before and the officially also bent down to that legal. ${ }^{7}$

Legal, and neither, not just only viewed as the rightest product of politics and exact to solves the every kind of problematics which is related with the act of corruption crime, but more than that, the legal that has been made is the result of crystallization of honest cultural from every layer of peoples in the middle of advancement of hedonism cultural from each of individual whom greedy and corrupt. The decision of court in revocation of politicals right is the incarnation from states wish to protects the right of hte people from the act of corruption crimes, it means the legal must be adapted with the advancement of the peoples, ${ }^{8}$ altough sometimes the states wish is considered to against the principle of legallity and considered to be ultra petita. This things has realized because of the weakness of the criminal punishment legal which is tend to be too and seems like what is looked like in the Law text but the fact it cant be giving the substantive justice to the peoples and state as the victims of act of corruption crimes.

Principles of legallity is not gave any protection function for the victims and/or society.

7 FX.Adji Samekto, "Relasi Hukum Dengan Kekuasaan: Melihat Hukum dalam Perspektif Realitas", Jurnal Dinamika Hukum, Vol. 13 No. 1, Januari 2013, Purwokerto: Law Faculty of Jenderal Soedirman University, page 95.

8 Agus Raharjo, "Problematika Asas Retroaktif dalam Hukum Pidana Indonesia", Jurnal Dinamika Hukum, Vol. 8 , No. 1, January 2008, Purwokerto: Law Faculty of Jenderal Soedirman University, page 70. 
Emptyness of protection function for the victims and/or society is the basic weakness and all at once the limited valid power of principles of legallity. Principles of legallity is powerless to charging the act which is causing the great loss for the individu and/or society, just because that depravity is not prohibit by the law of the criminal punishment. ${ }^{9}$

It proves that corruption has already give a dead loss for the society and states, because of that legal politics or legal policy in the sector of act of corruption crimes or criminal policy always oriented to recovering and bringing back the dead loss of the state which has already seized by the corruptor. Beside that, Barda Nawawi Arief revealed that criminal policy also must be have a clear addresed towards that main targets is to achieve the assuranc of legal that can be protects the the rights of the peoples and states to actualizing the social. ${ }^{10}$

In the viewside of Muladi towards the peoples and states whom already been the victims of the corruption crimes follow thar the victims is the peoples, either is good as individual or collective has been suffered of losses including dead losses of phsically or mentally, emotional, economics or substantial disturbance about fundamentalist rights, in the way of act of comission which is encroaching the law of criminal code in each of countries, and abuse of power. ${ }^{11}$

Indonesia is the intergralistic and communal country according to the social justice. Legal politics idealism or legal policy or criminal law or creating the legal policy in the future is in line with the models of theory prismatic

Deni SB Yuherawan, "Kritik Ideologis Terhadap Dasar Kefilsafatan Asas Legalitas Dalam Hukum Pidana“, Jurnal Dinamika Hukum Journal, Vol. 12 No. 2, May 2012, Purwokerto: Law Faculty of Jenderal Soedirman University, page 222 .

10 Tuti Budhi Utami, "Kebijakan Hukum Pidana dalam Menanggulangi Tindak Pidana Illegal Logging”, Jurnal Pembaharuan Hukum, Vol. 3 No. 2, Oktober 2007, Semarang: Law Studies Magister Program. Postgraduate of Diponegoro University, page 88.

11 Sri Wahyuni, "Kebijakan Hukum Pidana dalam Memberikan Perlindungan Hukum Terhadap Korban Tindak Pidana Kejahatan dalam Sistem Peradilan Pidana di Indonesia", Jurnal Pembaharuan Hukum, Vol. 4 No. 2, Oktober 2008, Semarang: Law Master Program, Postgraduate of Diponegoro University, page 81. from Fred W. Riggs, legal politics idealism which elaborate two tradition of patembayan laws and association or rechtstaat and common law, to produce the legal product that in line with the characteristic and cultural law of Indonesian peoples based on progressive law as a tools to eridicate the act of corruption crimes all at once as en engineering of anti-corruption acts. As emphasized by Pound Law as a tool social engineering.

The system of making the criminal policy (criminal law) in the model of prismatic is always based on the aim of states to achieve the people prosperity based on the social justice value. This means even the verdiction criminal punishment to the defendant of corruption such a revocation of political rights is considered tend to be not usual and contraversed with the constitution, but in the juridical constitution and the criminal code guaranteed towards the judges in doing them duty have an authority to makes a new breakthrough ideas in discovered law by progressive way especially in eridcation of act of corruption crimes, and its necessary to remember altough the constitution is guaranteed without any support by the brave and honest act from all of law enforcer element (implementing law) and the teamworks between society/the importance functionary surely the goal of erdication the act of corruption crime its just only empty hopes

Prismatic models of eradication the act of corruption crime means that eridication of act of corruption crime which based on the whole Pancasila value, futhermore in this transitional era which needed the creation of transitional jusice. Enforcement of law in transitional justice needed a new creative ideas from the law enforcer to enforce the law more wisely than just enforce the law in characteristic of autonomous law $^{12}$ which has been got a critized from Nonet and Selznick with their theory of responsive law.

\section{Closing \\ Conclusion.}

${ }^{12}$ FX. Adji Samekto, op.cit, page .95 
From the above description it can be conclude that follow: first, the existence of eradication of act of corruption crime in Indonesia is reffer to the Second Book Chapter XXVIII Criminal Code, Act Number 20 of 2001, Declaration of $8^{\text {th }}$ International Conference Against Corruption, and Indonesia United Nations Convention Against Corruption (UNCAC), UN Resolution 58/ 4 October 31 of 2003 and Act No.7 of 2006 on Ratificationof Anti-Corruption 2003; second, revocation of political rights for the defendant of Act of Corruption Crime altough tend to be inconstitutional, righteously must be done by the Judge to protect the advancement, law enforcement and to fulfill the human rights by the state trough the Government, such a message in Act 28I Paragraph (4) 1945 Constitutional; and third, needed a politics legal or legal policy agenda which based on the progressive with the basic assumption that legal for human, ${ }^{13}$ it means politic laws in the future is more emphasize to the sub system of cultural law than in substantial law or structural law.

\section{Suggestion}

According the above conclusion it can be suggested in the future in an effort of erdication of act of corruption crime is needed the judges attitude which are progressive and bravely to do the out of the book and than just become cone of criminal codes.

\section{Bibliography}

Alkostar, Artidjo. “Permasalahan Gratifikasi dan Pertanggungjawaban Korporasi dalam Undang-Undang Korupsi”. Varia Peradilan, Vol. XXVIII. No. 330. Mei 2013 Edition. Jakarta: Ikatan Hakim Indonesia;

Alting, Husen. "Penguasaan Tanah Masya-rakat Hukum Adat ((Suatu Kajian Terhadap Masyarakat Hukum Adat Ternate)". Jurnal Dinamika Hukum, Vol. 11 No. 1. Januari 2011. Purwokerto: Law Faculty of Jenderal Soedirman University;

Atmasasmita, Romli. "Korporasi Sebagai Subjek Tindak Pidana Korupsi”. Varia Pera- dilan, Vol. XXVIII. No. 330. May 2013. Jakarta: Ikatan Hakim Indonesia;

Rahardjo, Satjipto. 2006. Membedah Hukum Progresif. Jakarta: PT Kompas Media Nusantara;

Raharjo, Agus. "Problematika Asas Retroaktif dalam Hukum Pidana Indonesia". Jurnal Dinamika Hukum, Vol. 8. No. 1. January 2008. Purwokerto: Law Faculty of Jenderal Soedirman University;

Samekto, FX Adji. "Relasi Hukum Dengan Kekuasaan: Melihat Hukum dalam Perspektif Realitas". Jurnal Dinamika Hukum, Vol. 13 No. 1. Januari 2013 Edition. Purwokerto: Law Faculty of Jenderal Soedirman University;

Sidharta, Bernard Arief. 2009. Meuwissen Tentang Pengembanan Hukum. Ilmu Hukum. Teori Hukm dan Filsafat Hukum. Bandung: Refika Aditama;

Utami, Tuti Budhi. "Kebijakan Hukum Pidana dalam Menanggulangi Tindak Pidana Illegal Logging". Jurnal Pembaharuan Hukum, Vol. 3 No. 2. Oktober 2007. Semarang: Law Studies Magister Program. Postgraduate of Diponegoro University;

Wahyuni, Sri. "Kebijakan Hukum Pidana dalam Memberikan Perlindungan Hukum Terhadap Korban Tindak Pidana Kejahatan dalam Sistem Peradilan Pidana di Indonesia”. Jurnal Pembaharuan Hukum, Vol. 4 No. 2. Oktober 2008. Semarang: Law Magister Program. Postgraduate of Diponegoro University;

Yuherawan, Deni SB. "Kritik Ideologis Terhadap Dasar Kefilsafatan Asas Legalitas dalam Hukum Pidana “. Jurnal Dinamika Hukum, Vol. 12 No. 2. May 2012. Purwokerto: Law Faculty of Jenderal Soedirman University.

\footnotetext{
${ }^{13}$ Satjipto Rahardjo, op.cit, page 56-63.
} 